\title{
Brady $v$ Maryland and the Search for Truth in Criminal Trials
}

\author{
Robert Hochman†
}

Curtis Lee Kyles was convicted of shooting and killing a sixty year-old woman at the Schwegmann Brothers' grocery store in New Orleans. Following a mistrial due to a hung jury, Kyles was tried a second time, convicted of first-degree murder, and sentenced to death. ${ }^{1}$ At trial he claimed that one of the state's witnesses had framed him. Before the first trial, this witness changed his story to the police regarding how he knew Kyles and why he suspected that Kyles might be the murderer. Before the second trial, the witness again changed important elements of his story. However, the state disclosed none of these inconsistencies to the defense. Further, the police had evidence linking the witness to other crimes at Schwegmann Brothers', including an unrelated murder at that location. The police did not disclose this information to the defense; they did not even disclose it to the prosecutor. $^{2}$

Charles Jay Auten was convicted of conspiracy to negotiate stolen money orders. ${ }^{3}$ One of the government's key witnesses was an unindicted coconspirator who had been granted immunity before the trial. This witness admitted to a prior forgery conviction but denied any other convictions. Had the prosecutor directed a simple inquiry to the National Crime Information Center, he would have discovered two additional convictions. Because the prosecutor did not undertake such an inquiry, Auten could not aggressively impeach the witness's testimony. ${ }^{4}$

The defense in both of these cases sought new trials based on the Supreme Court's decision in Brady $v$ Maryland, which held that a prosecutor violates the Due Process Clause when he fails to disclose material evidence favorable to the accused. ${ }^{5} \mathrm{By}$ recognizing that basic fairness and the integrity of the criminal pro-

$\dagger$ B.A. 1993, Carleton College; J.D. Candidate 1997, The University of Chicago.

1 Kyles $v$ Whitley, 115 S Ct 1555, 1560 (1995).

2 Id at 1563-64, 1568.

3 United States $v$ Auten, 632 F2d 478, 480 (5th Cir 1980).

4 Id at 480-81.

573 US 83, 87 (1963). 
cess were at stake, Brady departed from the view of criminal trials as purely adversarial contests. The Brady rule rests on the notion that a criminal trial is a search for the truth. As Justice Fortas later asserted, "The State's obligation is not to convict, but to see that, so far as possible, truth emerges."

There are three elements to a successful Brady claim: "(a) suppression [of evidence] by the prosecution..., (b) the evidence's favorable character for the defense, and (c) the materiality of the evidence." The term "suppression" seems to have sprung from the Brady Court's understanding of pre-Brady cases. The Court traced the origin of the Brady rule to its 1935 decision in Mooney $v$ Holohan. ${ }^{8}$ That case involved a prosecutor's deliberate presentation of testimony known to be perjured. The Court held that the Due Process Clause "cannot... be satisfied by mere notice and hearing if a State has contrived a conviction through the pretense of a trial which in truth is but used as a means of depriving a defendant of liberty through a deliberate deception of court and jury." The Court later expanded the rule to include cases in which the prosecution does not solicit the "false evidence, [but] allows it to go uncorrected when it appears."

The early cases thus focused not on the suppression of evidence but rather on the presentation of evidence known to be false. Still, one could characterize these cases as suppression cases because the prosecutor did not disclose evidence that the defense could have used to impeach the false testimony. ${ }^{11} \mathrm{By}$ using the perjury cases in support of its holding, the Brady Court

6 Giles $v$ Maryland, 386 US 66, 98 (1967) (Fortas concurring). See also William J. Brennan, Jr., The Criminal Prosecution: Sporting Event or Quest for Truth? A Progress Report, 68 Wash U L Q 1, 18 (1990) ("Rules of fairness in a criminal trial must derive ... from careful attention to the trial's internal truth-finding function."). As one commentator has pointed out, a broad reading of Brady would fundamentally change the criminal process from an accusatorial to an inquisitorial system. Barbara Allen Babcock, Fair Play: Evidence Favorable to an Accused and Effective Assistance of Counsel, 34 Stan L Rev 1133, 1144 (1982). The Supreme Court has never explicitly recharacterized the criminal process as a search for truth. In response to Justice Fortas, Justice Harlan said in a dissenting opinion that the Constitution does not demand a fundamental "alter[ation in] the character and balance of our present systems of criminal justice." Giles, 386 US at 117 (Harlan dissenting).

7 Moore v Illinois, 408 US 786, 794-95 (1972).

8 Brady, 373 US at 86, citing Mooney v Holohan, 294 US 103, 112 (1935).

- Mooney, 294 US at 112.

10 Napue $v$ Illinois, 360 US 264, 269 (1959).

11 The Supreme Court has specifically held that prosecutors have a duty under Brady to disclose impeachment evidence. United States $v$ Bagley, 473 US 667, 676 (1985), citing Giglio v United States, 405 US 150, 154 (1972). 
implicitly incorporated their rationale, the search for truth, into its holding that the Due Process Clause prohibits "the suppression by the prosecution of evidence favorable to an accused ....."n

The Supreme Court's cases since Brady indicate that the government, to discharge its obligation, must sometimes seek out evidence favorable to the accused not yet in its possession. ${ }^{13}$ But the Court has offered extremely little discussion of how to circumscribe this rule. The Court's decisions in these cases fail to tell prosecutors when and where they must look to satisfy their disclosure obligations. ${ }^{14}$ Various federal and state courts have had more opportunities to wrestle with this issue, but they have not addressed it squarely. Loose language in some opinions has left the misleading impression that courts are stating strict rules;

12 Brady, 373 US at 87. The language of "suppression" has stuck, but it is somewhat misleading. As Mooney and Napue suggest, "suppression" connotes some intentional act of hiding evidence from the defense. Better would be the language of "disclosure," in the double sense of revealing what one has and uncovering what is necessary. See Victor Bass, Comment, Brady v. Maryland and the Prosecutor's Duty to Disclose, 40 U Chi L Rev 112,121 (1972) (arguing in favor of the language of "nondisclosure" instead of "suppression"). "Disclosure" communicates better Brady's character, since the obligation attaches regardless of the prosecutor's good faith or intent. Brady, 373 US at 87.

${ }_{13}$ Kyles, 115 S Ct at 1560, 1568 (holding the prosecutor responsible for evidence unknown to him but known to the police); Giglio $v$ United States, 405 US 150, 154 (1972) (holding a prosecutor responsible for information known by another prosecutor in his office); Pennsylvania $v$ Ritchie, 480 US 39, 58 (1987) (requiring trial court to examine government files not in the prosecutor's office).

14 The Supreme Court and commentators have focused on the standard of materiality, which concerns the effect the suppressed evidence could have had on the case and consequently whether the new trial remedy is appropriate. In short, the Court wants to ensure that the new trial has a good chance of reaching a different result because of the new, previously undisclosed evidence. See United States $v$ Agurs, 427 US 97 (1976), and United States $v$ Bagley, 473 US 667 (1985), both of which extensively analyze the materiality question. For commentary on the materiality standard, see generally Terrence J. Galligan, Comment, The Prosecutor's Duty to Disclose Exculpatory Evidence After United States v. Bagley, 1 Georgetown J Legal Ethics 213 (1987); Nicholas A. Lambros, Note, Conviction and Imprisonment Despite Nondisclosure of Evidence Favorable to the Accused by the Prosecution: Standard of Materiality Reconsidered, 19 New Eng J on Crim \& Civ Confinement 103 (1993). This Comment addresses the theoretically distinct issue of when the government has suppressed evidence, that is, when the government failed to disclose evidence it should have. One commentator has suggested that the standard of materiality should be related to how courts analyze nondisclosure. See Bass, Comment, $40 \mathrm{U}$ Chi L Rev at 123 (cited in note 12) (arguing that if the courts apply a stringent standard on the suppression prong of Brady, then the standard of materiality could be low).

For a discussion of the suppression or nondisclosure prong of the Brady analysis, see Stephen P. Jones, Note, The Prosecutor's Constitutional Duty to Disclose Exculpatory Evidence, $25 U$ Memphis L Rev 735, 756-61 (1994). This Note contains a good discussion of individual cases, but it does not offer much analysis of how to reconcile them, treating each case as an isolated event. 
however, more careful analysis reveals that these "rules" are often ad hoc and case specific, and they do not adequately describe the full range of Brady duties. Thus, prosecutors find themselves without proper guidance regarding their obligations, and defense attorneys find themselves without a clear sense of what they can expect.

This Comment clarifies how courts should approach Brady claims. It exposes the loose language of the courts, uncovers the various factors that affect Brady obligations, and demonstrates how the interaction of these factors, properly considered, yields a better account of the prosecutor's obligations. In addition, this Comment offers a new way to characterize Brady duties. Traditionally, Brady is understood as enunciating the duties only of the prosecutor. This Comment suggests that Brady is better understood as setting forth duties for all state actors, although it imposes special duties on prosecutors. This new understanding of procedural duties sheds light on the nature of the government's obligation in criminal cases to serve the truth. ${ }^{15}$

Part I distinguishes two kinds of Brady claims: "classic" and "search." Part II sets out the courts' descriptions of the prosecutor's search Brady obligations and shows their inadequacy. Drawing on the courts' holdings, it then presents a more precise account of the prosecutor's search Brady obligations. Part III revisits the case law to demonstrate that Brady imposes duties not only on prosecutors, but on all state actors. Part IV explains how this understanding of Brady clarifies the analysis and shows how it affects the results of Brady claims.

\section{Two KINDS OF BRADY ClaIMS}

This section reviews the Supreme Court's jurisprudence on Brady claims. It begins by classifying Brady claims as either classic Brady claims or search Brady claims. It then considers the elaboration of Brady in subsequent Supreme Court cases. While the Court has had several opportunities to revisit Brady, it has shed little light on the nature of Brady obligations.

The classic Brady claim involves the post-conviction discovery that the prosecutor failed to disclose to the defendant materi-

15 While a prosecutor may have a duty to disclose evidence to the defense under the Federal Rules of Criminal Procedure (Rule 16), under the Jencks Act, 18 USC $\S 3500$ (1994), or under rules of professional conduct, see the Model Rules of Professional Conduct Rule 3.8(d) (1995), this Comment discusses only the state's constitutional obligations under the Due Process Clause. 
al evidence in his possession that was favorable to the defense. In Brady, the prosecutor failed to disclose the statement of Brady's companion who had admitted strangling the victim in the murder for which they both were convicted. ${ }^{16}$ This statement, the Court found, was material to determining whether Brady should receive the death penalty. Because material evidence had been withheld, the Court ordered that Brady be resentenced. ${ }^{17}$ Although the background principles of the classic Brady claim remain important to this analysis, this Comment is primarily concerned with the state's obligations revealed by the second kind of Brady claim, what this Comment will call search Brady. ${ }^{18}$

A search Brady claim arises when the prosecutor fails to gather, or to receive from others, evidence that might be material and favorable to the defense. ${ }^{19}$ The Supreme Court has considered search Brady questions only three times. It has offered little analysis and has failed to explain fully the scope of search Brady duties.

In Giglio $v$ United States, the prosecutor handling the trial failed to disclose to the defense that the government had promised leniency to a key prosecution witness, a promise that the defense could have used as impeachment evidence. ${ }^{20}$ The prosecutor who handled the grand jury stage of the case had promised leniency but told the trial prosecutor that he had not. The trial prosecutor could not disclose to the defense that the promise had

16 Brady, 373 US at 84.

17 Id at 90.

18 While the terms "classic Brady" and "search Brady" are original, some courts have made the distinction. See, for example, United States $v$ Brooks, 966 F2d 1500, 1502 (DC $\mathrm{Cir}$ 1992) (distinguishing between the "duty to disclose exculpatory information" and the "duty to search possible sources for such information"); Commonwealth $v$ Donahue, 396 Mass 590, 487 NE2d 1351, 1355-56 (1986) (distinguishing between cases in which the prosecutor possesses the evidence and those that oblige the prosecutor to obtain exculpatory evidence from elsewhere).

19 Some courts appear to deny that the prosecutor ever has a duty to search for information not in his actual possession. See United States $v$ Escobar, 842 F Supp 1519, 1530 (E D NY 1994) (rejecting request to have prosecutor examine government agentwitnesses' personnel files because "the prosecutor is not responsible for knowing what is in the files of other agencies"); United States $v$ Moore, 25 F3d 563, 569 (7th Cir 1994), cert denied as Anderson v United States, 115 S Ct 341 (1994) (rejecting notion that prosecutor had duty to use due diligence to discover exculpatory evidence since "Brady simply does not apply unless the prosecutor had knowledge of the exculpatory information"); Commonwealth $v$ Daigle, 379 Mass 541, 399 NE2d 1063, 1068 (1980) ("The Commonwealth is not obligated to collect and assemble the criminal records of its witnesses for the defendant."). As the following discussion makes clear, to the extent that these cases mean to deny the possibility of search Brady claims, they are incorrect.

20405 US 150, 150-51 (1972). 
been made because he did not know about it. Nonetheless, the Court, citing principles of agency but offering little analysis, attributed knowledge of the promise to the trial prosecutor and ordered a new trial. ${ }^{21}$

In Pennsylvania $v$ Ritchie, the Supreme Court implicitly recognized that Brady may require the prosecutor to examine files held by other government agencies to determine whether they contain any material evidence favorable to the defense. ${ }^{22}$ The defendant was charged with raping his thirteen year-old daughter. Under Pennsylvania law, Pennsylvania's Children and Youth Services (CYS), a state agency that investigates cases of suspected mistreatment, could only release its confidential reports under certain enumerated circumstances. At the time of Ritchie's trial, those situations did not include release to law enforcement officials for use in a criminal investigation. ${ }^{23}$ As a result, the prosecutor had not seen the file, did not have access to it, and, accordingly, did not comply with the defense request to provide it. Nonetheless, the court held that, under Brady, Ritchie was "entitled to have the CYS file reviewed ... to determine whether it contains information that probably would have changed the outcome of his trial. ${ }^{\text {m2 }}$ The Court never actually discussed why the prosecutor must review the file. In fact, the Court seemed unaware that it was passing on a search Brady claim at all. ${ }^{25}$

In Kyles $v$ Whitley, discussed above, the Court explicitly extended the holding in Giglio beyond the prosecutor's office. ${ }^{26}$ The Court held that the prosecutor remains responsible for pro-

21 Id at 152-55.

22480 US 39, 57-60 (1987). The mere failure to examine the file is not necessarily a Brady violation calling for a new trial. A violation has occurred only if the evidence that the state actor ought to have examined actually turns out to contain material and exculpatory evidence. Id at 61 . See text accompanying note 7 .

23 Id at $44 \mathrm{n} 2$.

24 Id at 57-58. It is worth noting that the Ritchie Court ordered a review of the file by the trial court, not the prosecutor. This may have been in deference to the Pennsylvania statute, which allowed an exception to its confidentiality rule when a "court of competent jurisdiction [issues] a court order." Id at $44 \mathrm{n} \mathrm{2,} \mathrm{quoting} 11 \mathrm{~Pa}$ Stat Ann $\S 2215$ (a) (Purdon Supp 1986). Ordinarily, since the duty of disclosure belongs to the government, the prosecutor will review the file himself, without submitting it to the court. Conceivably, the Supreme Court could have ordered the trial court to issue an order allowing the prosecutor to review the file. Why it did not is something of a mystery. See Brooks, 966 F2d at 1504-05 (citing cases).

${ }_{25}$ As the D.C. Circuit later noted, the Ritchie court "appears to have assumed" that Brady requires the prosecutor to search government files outside of her office. Brooks, 966 F2d at 1502.

26115 S Ct 1555, 1567-68 (1995). 
ducing evidence favorable to the defense even when police fail to bring such evidence to the prosecutor's attention. ${ }^{27}$ The Court provided a brief justification for holding the prosecutor responsible for what the police knew: "[A]ny argument for excusing a prosecutor from disclosing what he does not happen to know about boils down to a plea to substitute the police for the prosecutor, and even for the courts themselves, as the final arbiters of the government's obligation to ensure fair trials."28

In none of these cases has the Supreme Court specified how far the prosecutor must go to find evidence favorable to the accused. In the absence of guidance from the Supreme Court, lower courts have struggled to define the scope of the prosecutor's duties to search for the truth and disclose evidence. The next section explores the different approaches adopted by the courts.

\section{SEARCH BRADY OBLIGATIONS IN THE LOWER COURTS}

Left to their own devices, lower courts are in disarray over the precise scope of Brady duties and the proper rationales behind them. This section explores the approaches taken by those courts. In particular, it highlights a disjunction between the stated rationales the courts offer to explain their decisions and the actual factors that underlie their rulings.

The clearest cases of nondisclosure involve evidence that is both in the government's possession and unavailable to the defense. Technically speaking, the prosecution cannot disclose that which it does not possess. ${ }^{29}$ However, relying on Giglio, the courts have recognized that actual possession by the prosecutor is not essential to a Brady claim; constructive possession will do. Once we recognize that evidence constructively possessed can be the basis of a Brady claim, we have recognized the possibility of search Brady claims. Some courts, however, refuse to extend that

${ }^{27}$ Id at 1560 . This "extension" surprised no one. Courts had consistently held prosecutors responsible for information held by the police prior to Kyles. Wayne R. LaFave and Jerold H. Israel, Criminal Procedure $\S 20.7$ at 893 (West $2 d$ ed 1992) ("Lower courts have regularly held that the prosecution's [disclosure] obligation ... extends to the files of those police agencies that were responsible for the primary investigation in the case.").

${ }^{28}$ Kyles, $115 \mathrm{~S} \mathrm{Ct}$ at 1568.

29 See, for example, United States v Meros, 866 F2d 1304, 1309 (11th Cir 1989) (Brady only applies to the prosecutor and those under his authority.); United States $v$ Dominguez-Villa, 954 F2d 562, 566 (9th Cir 1992) (prosecution under no duty to turn over materials not under its control); Commonwealth v Tucceri, 412 Mass 401, 589 NE2d 1216, 1220 (1992) (Brady duties extend only to evidence in the possession of prosecutor or police officers who worked on the case.). 
rationale to situations in which the defense can obtain the information without the prosecutor's aid.

The following subsections survey the courts' language regarding search Brady claims. The narrow holdings in this area are often difficult to express as broad propositions, and although the courts often speak as if they are laying down general rules, careful analysis reveals that they are not. Instead, the courts are focusing on particular factors of importance in determining the prosecutor's search Brady obligations. Taken together, the cases reveal that in search Brady cases, courts use three competing notions to address the issue of the prosecutor's constructive possession of evidence and a fourth to address the availability of evidence to the defense.

\section{A. What Courts Say}

1. Same-sovereign constructive possession.

Borrowing from the language in Rule 16(a)(1)(C) of the Federal Rules of Criminal Procedure, some courts have stated that no Brady obligations arise unless the evidence at issue is within the "government's actual possession, custody, or control." "no Evidence held exclusively by agents of a separate sovereign (for example, federal rather than state agents or agents of another state government) is not considered in the possession, custody, or control of the prosecutor. ${ }^{31}$

The Giglio Court's reference to agency theory may justify circumscribing the scope of search Brady obligations to the extent of a single sovereign. ${ }^{32}$ The First Circuit has analogized the single-sovereign approach to the doctrines of corporate criminality. Such responsibility, the court pointed out, is "founded on the collective knowledge of its individual employees and agents. There is no reason why similar principles of institutional respon-

30 United States $v$ Dominguez-Villa, 954 F2d 562, 566 (9th Cir 1992) (citing FRCrP 16(a)(1)(C)). The Ninth Circuit has made clear elsewhere that this rule applies under Brady as well as the Federal Rules. See United States $v$ Aichele, 941 F2d 761, 764 (9th Cir 1991), citing United States $v$ Gatto, 763 F2d 1040, 1049 (9th Cir 1985) ("The prosecution is under no [Brady] obligation to turn over materials not under its control.").

31 Dominguez-Villa, 954 F2d at 566; Aichele, 941 F2d at 764. See also United States $v$ Walker, 720 F2d 1527, 1535 (11th Cir 1983) (stating "we do not believe that knowledge of any deal between state officials and [a witness] can be imputed to the federal prosecutor"); United States $v$ Kern, 12 F3d 122, 126 (8th Cir 1993) (refusing to "impute the knowledge of the State of Nebraska to a federal prosecutor").

32 Giglio, 405 US at 154 (discussing procedures to insure communication of "all relevant information" in prosecutor's office). 
sibility should not be used to analyze the actions of individual government attorneys called upon to represent the government as an institution in matters of ... disclosure obligations. ${ }^{n 33}$ The prosecutor represents the sovereign for which she works. She is an agent of that government and that government alone. She cannot be held responsible for information held outside the institution that she represents.

Yet the single-sovereign approach produces awkward results. In the war on drugs, joint state and federal prosecutions have become common. It seems bizarre in such a situation to grant a new trial if a federal prosecutor fails to disclose information held by the FBI, but not if the same information was held by the local police aiding the investigation. United States $v$ Dominguez-Villa provides another good illustration..$^{34}$ In that case, the court required the federal prosecutor to review, for possible impeachment evidence, the personnel files of all federal agents who were going to testify at trial. However, the court refused to require precisely the same review of the personnel files of state police officers who were to testify. ${ }^{35}$ These absurd results show that requiring samesovereign possession as a necessary condition of a search Brady claim goes too far. Such an approach draws arbitrary lines and too easily allows the government to suppress or avoid the truth, contrary to Brady's motivating principle.

\section{Constructive possession within the prosecution team.}

Other courts have suggested that search Brady obligations extend to what they call the "prosecution team." ${ }^{36}$ Different courts have defined the prosecution team in different ways. New York courts, for example, have limited the prosecution team to personnel working for "law enforcement agenc[ies],"37 excluding agencies that perform "separate administrative functions." Federal courts have tended to define the prosecution team with broader language. The Fifth Circuit, for example, has "declined to draw a distinction between different agencies [of government], focusing instead on the 'prosecution team' which includes both

33 United States $v$ Osorio, 929 F2d 753, 761 (1st Cir 1991) (citations omitted).

34 954 F2d 562, 565 (9th Cir 1992).

${ }^{35}$ Id at 565-66.

36 See, for example, United States $v$ Antone, 603 F2d 566, 569 (5th Cir 1979); United States $v$ Spagnoulo, 960 F2d 990, 994 (11th Cir 1992) (citation omitted).

${ }^{37}$ People $v$ Berkley, 157 AD2d 463, 549 NYS2d 392, 394 (NY App Div 1990).

${ }_{38}$ People $v$ White, 210 AD2d 446, 620 NYS2d 437, 438 (NY App Div 1994), citing People $v$ Kelly, 209 AD2d 436, 618 NYS2d 822, 825 (NY App Div 1994). 
investigative and prosecutorial personnel. ${ }^{n 39}$ The language may be different, but the thrust is the same. The prosecution team consists of agents who had important contact with the prosecution during either the investigation or prosecution of the case. ${ }^{40}$

The prosecution team approach rejects sovereignty as a relevant consideration. Instead, the extent of cooperation is determinative. If the court finds in a federal prosecution that "state agents were in a real sense members of the prosecutorial team," it will consider evidence in the possession of the state agents to be constructively possessed by the prosecutor. ${ }^{41}$ Under this approach, the prosecutor represents not only the sovereign for which she works, but also all of the various government agents who worked with her and provided her information leading to the prosecution. $^{42}$

The "prosecution team" language makes more sense than drawing an arbitrary line at sovereignty. This approach more realistically accounts for intersovereign cooperation and avoids the formalism of the single-sovereign approach. Still, there are problems with this approach as well. A state file not held by a state member of the prosecution team might contain evidence favorable to the accused. If the prosecutor knows this and can easily obtain the evidence, why should she not be required to obtain it and disclose it to the defense? ${ }^{43}$ Although some courts have suggested that possession by the prosecution team is neces-

39 Antone, 603 F2d at 569 (citations omitted). See also United States $v$ Meros, 866 F2d 1304, 1309 (11th Cir 1989) ("Brady ... applies only to information possessed by the prosecutor or anyone over whom he has authority."); Smith $v$ Fairman, 769 F2d 386, 391 (7th Cir 1985) (Brady applies to information held by "a state instrumentality closely aligned with the prosecution.").

${ }^{40}$ Antone, $603 \mathrm{~F} 2 \mathrm{~d}$ at 569 (finding Brady violation where state and federal governments "pooled their investigative energies to a considerable extent"); Berkley, 549 NYS2d at 394 (rejecting Brady claim because rape counseling center's refusal to turn over victim's statements to prosecutors established that the two entities were not working together); United States $v$ Wood, 57 F3d 733, 737 (9th Cir 1995) (holding that when agency "has consulted with the prosecutor in the steps leading to prosecution," evidence held by that agency will be treated the same as evidence held by the prosecutor himself).

41 Antone, 603 F2d at 570.

42 There is some Supreme Court language supporting this view. In Kyles, the Court stated that the prosecutor "has a duty to learn of favorable evidence known to the others acting on the government's behalf in the case ..." $115 \mathrm{~S} \mathrm{Ct}$ at 1567. However, the facts of the case involved evidence suppressed by local police in a local prosecution. It is possible that the Court will restrict Kyles to its facts if faced with a cross-sovereignty case.

${ }^{43}$ See United States $v$ Auten, 632 F2d 478, 481 (5th Cir 1980) (finding a Brady violation when the prosecutor failed to run an FBI or National Crime Information Center check to uncover the complete criminal record of a witness). 
sary for a valid search Brady claim, this proposition is too general to describe accurately such an unsettled area of law. ${ }^{44}$

\section{Availability of the evidence to the prosecutor.}

Recognizing that the prosecution team notion may be underinclusive, some courts have suggested that the prosecution has constructive possession of any "information readily available to it." 45 According to this view, the notion of the prosecution team does not express the full extent of the government's duties. "The 'prosecution team' concept does not ... relieve the government of its duty to inquire about Brady information when the known facts warrant further inquiry into facts readily available. ${ }^{\$ 46}$ This view requires the prosecutor to acquire certain items not within his (or his sovereign's or team's) actual possession. The court would then hold that the prosecutor had constructive possession because he easily could have had actual possession.

For instance, in United States $v$ Deutsch, the defendants were convicted of bribing a postal employee. ${ }^{47}$ When the defendants asked for the personnel file of the employee whom they were accused of bribing, the prosecutor replied that he did not possess it, and the trial court, supporting the prosecutor, held the post office was not an arm of the prosecution. The appellate court faulted the prosecution for failing to obtain the file, declaring that 'different 'arms' of the government, particularly when ... closely connected ... are [not] severable entities." The court focused on how easily the prosecutor could have obtained the file. In fact, the court seemed irritated that, given the ease with which the file could have been acquired, the prosecutor failed to get it. ${ }^{49}$

4 Nonetheless, in those circuits using the prosecution team language, a Brady claim may require showing that the evidence was held by a member of the prosecution team. See text accompanying notes 36-40. But the Supreme Court has never affirmed this rule.

is United States $v$ Auten, 632 F2d 478, 481 (5th Cir 1980); Williams $v$ Whitley, 940 F2d 132, 133 (5th Cir 1991). See also United States $v$ Perdomo, 929 F2d 967, 970 (3d Cir 1991) (holding that "the prosecution is obligated to produce certain evidence actually or constructively in its possession or accessible to it").

46 United States v Burnside, 824 F Supp 1215, 1257 (N D ml 1993).

47475 F2d 55, 56 (5th Cir 1973), overruled on other grounds as United States $v$ Henry, 749 F2d 203 (5th Cir 1984).

${ }^{18}$ Deutsch, 475 F2d at 57. See also Martinez $v$ Wainwright, 621 F2d 184, 186-89 (5th Cir 1980) (requiring state prosecutor to go to FBI to acquire rap sheet of victim in murder trial).

49 Deutsch, 475 F2d at 57 (The prosecution "did not even deny access, but only 
The language of "readily available" information, while applicable in the variety of circumstances in which search Brady claims arise, lacks some of the clarity that the other "rules" provide. To be sure, "no formula defining the scope of the duty to search can be expected to yield easily predicted results. ${ }^{350}$ But courts should aspire to give more detailed guidance to prosecutors and defense attorneys than they have in these cases.

\section{Availability of the evidence to the defendant.}

Sometimes courts suggest that a search Brady claim might succeed or fail depending on how easy it is for the defendant to find the evidence on his own, regardless of how easy it is for the prosecutor to obtain it. ${ }^{51}$ Brady is not supposed to shift the job of defense investigation to the prosecution. The defendant will not have a Brady claim, these courts say, if, with "reasonable diligence," he could have uncovered the evidence without the aid of the prosecutor. ${ }^{52}$ If the defendant could have uncovered the evidence without the aid of the prosecutor, then the defendant's failure to do so is his own fault and not attributable to the prosecutor. This means that if the defendant knew of the possibility that a government office had exculpatory information and that office was subject to subpoena, then the failure to subpoena the information will negate a search Brady claim. ${ }^{53}$

A broad availability-to-the-defendant rule is inadequate. Such a broad rule would punish the defendant severely for his attorney's incompetence, even in a case of clear prosecutorial impropriety. For example, if the prosecution's key witness has a

present possession without even an attempt to remedy the deficiency.").

so United States $v$ Brooks, 966 F2d 1500, 1504 (DC Cir 1992).

51 The availability of the evidence to the defense is not a matter of constructive possession by the prosecutor. Rather, it is a way for the prosecutor to defeat a Brady claim despite his constructive possession of the evidence.

${ }^{52}$ See, for example, United States $v$ Boyd, 833 F Supp 1277, 1354 (N D Ill 1993), aff'd, 55 F3d 239 (7th Cir 1995) (The scope of the prosecutor's duty to search "excludes information that the defense either (i) had actually obtained prior to trial through some independent means, or (ii) could have discovered through the exercise of reasonable diligence.") (citations omitted); United States v Aichele, 941 F2d 761, 764 (9th Cir 1991) ("When ... a defendant has enough information to be able to ascertain the supposed Brady material on his own, there is no suppression by the government.") (citations omitted); United States $v$ Ellender, 947 F2d 748, 757 (5th Cir 1991) ("[W] here the defendant's own lack of reasonable diligence is the sole reason for not obtaining the pertinent material, there can be no Brady claim.").

${ }_{53}$ Boyd, 833 F Supp at 1357 ("It is well settled that defendants cannot base a Brady claim on information that could have been obtained from other sources via subpoena.") (citing cases). 
long criminal record, then the prosecutor must disclose this information to the defendant in the interest of truth and fairness. Why should it matter whether the defense attorney failed, through incompetence, to seek independently the witness's criminal record, even though such an investigation would have been easy? ${ }^{54}$ Any court ignoring the prosecutor's failure to disclose such information "would be inviting and placing a premium on conduct unworthy of representatives of the United States Government ${ }^{n 5}$ - unworthy in the sense that it demonstrates indifference to the truth. To be sure, the defense attorney bears responsibility for failing to uncover the evidence, but the defense attorney's failure to do his duty does not relieve the prosecutor of his own duty to seek the truth.

\section{B. The Meaning Behind the Language}

A careful analysis of the case law reveals that the "rules" set out above fail to tell the whole story. Rather, courts look to several related but distinct factors in reaching their decisions. The law appears confused because courts do not always articulate all of the relevant factors in particular cases. This leaves the inaccurate impression that one factor alone disposes of the question.

The courts consider four basic factors in reaching their conclusions. First, courts examine the context in which the evidence is found and its relation to the case. The closer the relation between the context and the case, the more likely courts are to find a violation. Second, courts examine the effort a prosecutor must expend to uncover the evidence. As that effort grows, courts become less likely to find a violation. Third, courts examine the likelihood, based on what the prosecutor knows, that the evi-

54 At this point, the Brady obligation begins to overlap with a claim for ineffective assistance of counsel. See Strickland $v$ Washington, 466 US 668, 686 (1984) ("The benchmark for judging any claim of ineffectiveness must be whether counsel's conduct so undermined the proper functioning of the adversarial process that the trial cannot be relied on as having produced a just result."). The important point is to ensure that we have rules that can correct for incompetence when it appears, but that do not adversely affect the incentives of good defense attorneys. Here, we need not worry about competent defense attorneys failing to conduct independent investigations. Defense attorneys know that the prosecutor is neither capable of disclosing nor obliged to disclose all relevant evidence favorable to the defense. Prosecutors cannot recognize as well as defense attorneys the significance of a particular item of evidence in the context of the defense's entire case. Further, the materiality standard allows certain favorable evidence that the defense would surely want to obtain to remain undisclosed. For further discussion on how reliance on the state's Brady obligations does not substitute for good defense investigation, see notes 83 and 105.

${ }_{35}$ United States v Auten, 632 F2d 478, 481 (5th Cir 1980). 
dence, as yet unexamined by the defense, will turn out to be material and favorable to the defense. As the evidence becomes more likely to have a substantial impact on the case, courts become more inclined to find Brady obligations. Finally, courts look at the ease with which the defendant could obtain the evidence. The easier it is for the defendant to uncover the evidence without prosecutorial aid, the harder it is for him to prevail on his Brady claim. ${ }^{56}$

These four factors seek to describe how the courts should determine whether a prosecutor has behaved with due regard for the need to uncover the truth. They help courts understand what a prosecutor should have known and, therefore, disclosed to the defense. They do not lend themselves to precise quantification, but rather involve an imprecise balancing. While no formula can possibly describe every case, these factors provide a good framework for analysis. Further, while the overall analysis is imprecise, some relatively precise rules appear. For example, the context and potential-impact-on-the-case factors impose necessary minimum standards on the overall analysis. Without reaching their minimum thresholds, a search Brady claim cannot succeed no matter how strong the presence of the other factors.

\section{Context.}

The closer the relation between the context in which the evidence is found and the key issues in a case, the stronger the defendant's Brady claim becomes. Interestingly, however, physical closeness can differ from the contextual, functional closeness.

The facts of United States $v$ Joseph illustrate how evidence can be physically close to the prosecutor but functionally far away. ${ }^{57} \mathrm{~A}$ government agent served as a key eyewitness for the prosecution and claimed that he saw the defendant engage in a drug transaction between 6:00 and 6:30 p.m. on the day in ques-

${ }^{56}$ The Massachusetts Supreme Judicial Court has identified a similar set of basic factors of search Brady problems. See Commonwealth $v$ Donahue, 396 Mass 590, 487 NE2d 1351, 1356 (1986) (listing "the potential unfairness to the defendant; the defendant's lack of access to the evidence; the burden on the prosecutor of obtaining the evidence; and the degree of cooperation between State and Federal authorities, both in general and in the particular case"). The degree of cooperation between the prosecutor and the agency in possession of the evidence is important to what this Comment terms the context factor. Further, the potential unfairness to the defendant is another way of stating the potential impact of the evidence on the case. See text accompanying note 71. United States v Brooks, 966 F2d 1500 (DC Cir 1992), offers the most thorough judicial analysis of a search Brady case to date.

${ }_{57} 996$ F2d 36, 38-40 (3d Cir), cert denied 114 S Ct 357 (1993). 
tion. In an unrelated case, previously handled by the same prosecutor, the same officer had testified to being in a different location at that time. The prosecutor actually possessed the file containing this impeachment evidence but did not notice the inconsistency. The court did not find a Brady violation and held that the prosecutor's conduct was reasonable. Since both prosecutions were for possession of a controlled substance (rather than distribution), the particular times that each surveillance took place were "just not an important element" in either case, and therefore not something that one should expect the prosecutor to have noticed. $^{58}$

Conversely, evidence physically far from the prosecutor can be functionally close to him. In People $v$ Rutter, tried in New York, the prosecutor put on a witness who claimed to have observed the alleged murder..$^{5}$ The witness had taken a polygraph test administered by the Philadelphia police, during which she had stated that she had not seen the murder. The prosecutor claimed that he did not violate Brady, since the Philadelphia police did not apprise him of the existence of the evidence until mid-trial. The court rejected this argument and found that the prosecutor's late disclosure of the polygraph transcript violated Brady. ${ }^{60}$ Noting that New York and Philadelphia authorities had worked together closely in investigating the crime, the court held the New York prosecutor responsible for locating and disclosing the evidence in a timely fashion, even though the evidence was in Philadelphia. ${ }^{61}$

Still, the context factor does impose a strict physical limit on search Brady obligations. Evidence in the hands of private parties is never subject to a search Brady claim. ${ }^{62}$ Only evidence in the possession of some arm of some government can trigger a valid Brady claim. Moreover, Brady does not impose a general duty on the government to investigate. ${ }^{63} \mathrm{~A}$ general duty would require unrealistic diligence from prosecutors with limited resources.

58 Id at 40.

69 202 AD2d 123, 616 NYS2d 598, 600-01 (NY App Div 1994).

so The polygraph transcript was not made available to the defense until after the witness had testified. The trial court denied a defense request for cross-examination based on the new evidence. Id at 601 .

61 Id at 603-04.

${ }^{6}$ Deutsch, $475 \mathrm{~F} 2 \mathrm{~d}$ at 57 (The prosecutor is not "obliged to obtain evidence from third parties.").

${ }^{63}$ Arizona v Youngblood, 488 US 51, 59 (1988) (rejecting the contention that "the Due Process Clause is violated when the police fail to use a particular investigatory tool"). 


\section{The burden on the prosecutor.}

The burden and context factors substantially overlap. Defining context functionally suggests that evidence which is "close" enough to the prosecutor is not terribly difficult for him to acquire. But when the burden on the prosecutor is only slight, his duty to search stretches beyond functionally close places. If the prosecutor can easily acquire the evidence, it may not matter which state agent possesses it.

For example, state and federal prosecutors can easily obtain the criminal records of individuals involved in a trial, since the FBI routinely provides them criminal records on request. This fact places the burden of acquiring those records on prosecutors, even when it involves contacting an agent not involved in prosecuting the case. ${ }^{64}$ Similarly, an examination of a testifying officer's personnel file may be necessary in order to ensure that it does not contain any impeachment evidence. ${ }^{65}$

The cases stressing the ease of the prosecutor's effort suggest that the defendant must make specific requests for evidence. ${ }^{66}$ Such precise requests can indeed ease the prosecutor's burden

64 See, for example, Martinez $v$ Wainwright, 621 F2d 184, 186-89 (5th Cir 1980) (requiring state prosecutor to go to FBI to acquire rap sheet of victim in murder trial); United States v Auten, 632 F2d 478, 481 (5th Cir 1980) (requiring federal prosecutor to run an FBI or National Crime Information Center check on a witness to uncover the witness's prior record). But see Commonwealth v Daigle, 370 Mass 541, 399 NE2d 1063, 1068 (1980) ("The Commonwealth is not obligated to collect and assemble the criminal records of its witnesses for the defendant.").

${ }_{65}$ See, for example, United States v Henthorn, 931 F2d 29, 31 (9th Cir 1991) (requiring federal prosecutor to examine personnel file of testifying Drug Enforcement Agency and customs agents); Dominguez-Villa, 954 F2d at 565 (rejecting the government's claim that the defendant must make an initial showing of materiality to compel the examination).

Examining a testifying officer's personnel file is more controversial than running a check on other witnesses. Some courts, unlike Dominguez-Villa, require the defendant to show some reason to believe that the examination will reveal evidence favorable to the defense. See United States v Andrus, 775 F2d 825, 842-43 (7th Cir 1985) (finding no need for prosecution to turn over testifying officers' personnel files when the request was based on "[m]ere speculation"); United States $v$ Romo, 914 F2d 889, 898-99 (7th Cir 1990), quoting Andrus, 775 F2d at 843 (refusing to compel search of police officers' personnel files "without even a hint that impeaching material was contained therein"). Here, the burden factor intersects with the factor weighing the potential impact of the evidence on the case-as the evidence becomes more likely to be material, the prosecutor must accept a greater burden to acquire it.

${ }_{66}$ See, for example, Henthorn, $931 \mathrm{~F} 2 \mathrm{~d}$ at 31 ("The obligation to examine the files arises by virtue of the making of a demand for their production."); Auten, 632 F2d at 480 (emphasizing that defendant had called possibility of witness's convictions to the attention of the prosecutor in his discovery request); Martinez, 621 F2d at 185-86 (noting that defendant requested victim's rap sheet before, during, and after trial). 
and should be considered in evaluating a subsequent Brady claim. When the prosecutor's search might be burdensome, a specific request can lighten the burden so as to impose an obligation on the prosecutor to execute the search. A defendant can trigger an obligation to examine files that are seemingly unrelated to his case by making a specific request that "explicitly identifies the desired material and is objectively limited in scope. ${ }^{n 67}$ Of course, the state must also possess the evidence that the defendant requests.

But specific requests should not be considered necessary, especially regarding witnesses whose testimony is crucial to the prosecution's case. ${ }^{68}$ That is, as the potential materiality of the evidence increases, the court is less likely to require the defense specifically to request evidence. The prosecutor should always check on the backgrounds of his key witnesses. ${ }^{69}$ A specific-request requirement constitutes a trap for the unwary defense counsel who neglects to request specifically the rap sheet of a key government informant. ${ }^{70}$ In general, when the prosecutor can easily access a state file with evidence potentially favorable to the accused, he should examine it. Of course, once the prosecutor examines the file, classic Brady obligations apply.

\section{Potential impact on the case.}

Courts are more likely to impose search Brady obligations when they find that the prosecutor had reason to believe that the file contained material evidence favorable to the defense at the time the search should have taken place. Because such "reason to believe" deals with an unknown, courts have set a very low

${ }^{67}$ Joseph, 996 F2d at 41. See also United States $v$ Brooks, 966 F2d 1500, 1503 (DC Cir 1992) (finding it "highly relevant that defense counsel pinpointed files that can be searched without difficulty").

68 Brooks, 966 F2d at 1503 (noting that the Auten court did not need to explain why the prosecutor had to acquire the criminal record of its key witness since the "link to the case" was clear).

Two courts have noted the incentive already in place for prosecutors to examine the backgrounds of their key witnesses. Id at 1502-03 ("Of course the prosecutor's own interest in avoiding surprise at trial gives him a very considerable incentive to search accessible files for possibly exculpatory evidence, quite independent of Brady."); United States $v$ Osorio, $929 \mathrm{~F} 2 \mathrm{~d}$ 753, 761 (1st $\mathrm{Cir}$ 1991) ("No properly prepared trial lawyer should permit himself to be surprised by the vulnerability of his witness .... .").

${ }^{70}$ Justice Brennan has argued that criminal discovery rules should not be based on a sporting conception of fairness in which the rules are "designed to ensure that the person or team with the best skills wins. . . . Rules of fairness in a criminal trial must derive not from some effort evenly to match the sides ... but from careful attention to the trial's internal truth-finding function." Brennan, 68 Wash U L Q at 18 (cited in note 6). 
threshold for likely impact. Assuming the other factors support a search Brady claim, courts reject such a duty only when it rests on "utter speculation" that the file in question contains exculpatory information. ${ }^{71}$

\section{Availability of the evidence to the defense.}

Some courts reject search Brady claims if they conclude that the exculpatory evidence was readily available to the defense. ${ }^{72}$ These courts are rightly concerned with allowing defense attorneys to send prosecutors on wasteful searches. But these courts also fail to recognize that the defense attorney's ability to manipulate the prosecution changes dramatically once the defendant has been convicted.

The rationale for refusing to honor a Brady claim because the evidence is available to the defense makes sense in pre-conviction defense requests. If the evidence is available to the defense (for example, through subpoena) and the prosecutor does not think that it is important enough to review, then the prosecutor should not be put to the trouble. ${ }^{73}$ Since the subpoena would give the defendant everything to which he is entitled, putting the burden on the prosecutor is wasteful. Further, defense counsel will always prefer to examine the files himself rather than trust the prosecutor to determine the significance of the evidence to the defense case.

But when confronted with a post-conviction search Brady claim, the analysis changes. Where the defense knows about accessible information helpful to its case before trial, it may properly obtain that information itself without help from the prosecutor. But if the defense only learns of such information after the defendant is convicted, its prior availability is irrelevant. Defendants are no longer in a position to manipulate prosecutorial resources. If the other factors favoring a search Brady claim impose an obligation on the prosecutor, the prior availability of the evidence does not mitigate that obligation. ${ }^{74}$

${ }^{11}$ United States $v$ Brooks, 966 F2d 1500, 1504 (DC Cir 1992). See also United States $v$ Navarro, 737 F2d 625, 630-31 (7th Cir 1984) (rejecting a claim based on "mere speculation").

${ }^{72}$ See text accompanying notes 51-55.

${ }^{73}$ See Commonwealth v Donahue, 396 Mass 590, 487 NE2d 1351, 1355 (1986) (recognizing that "the Brady rule is tempered by ... the practical concern that the prosecutor not be so burdened that the administration of justice is unduly hampered"); Joseph, 996 F2d at 41 (expressing concern that defense attorneys will send prosecutors on "open-ended fishing expeditions").

${ }^{74}$ To hold otherwise would encourage duplicative investigations: 
Taken together, the cases identify factors relevant to determining a prosecutor's disclosure duties, although some courts use just one. The contextual location of the evidence, the ease with which the prosecutor can acquire it, and the potential impact on the case better describe when the prosecutor constructively possesses evidence than any artificial line drawing. Further, the prosecutor's duty is rebutted when the disclosure request comes before trial and the evidence is readily available to the defense.

\section{REVISITING SEARCH BRADY OBLIGATIONS: OBLigations BEYOND THE PROSECUTOR'S OFFICE}

This Section reconceptualizes Brady obligations and the corresponding Brady claims. Up to now, we have considered only how far prosecutors must go to satisfy their Brady obligations. This Section deals with who has Brady obligations. Both prosecutors and other state actors should bear Brady obligations. While both types of state actors should bear Brady obligations, the extent of their obligations should differ. Prosecutors should bear both classic Brady and search Brady obligations; nonprosecutors should only bear classic Brady obligations.

\section{A. Whose Duty Is It Anyway?}

In order to state adequate rules for how to approach search Brady claims, we should reassess how we conceptualize Brady obligations. The classic formulation of Brady as the prosecutor's duty to disclose material evidence favorable to the accused in his possession is an obstacle to properly understanding nondisclosure of evidence by the government.

The convention of characterizing Brady as the prosecutor's duty is understandable for at least two reasons. First, the prosecutor usually delivers exculpatory evidence to the defense. He is the liaison between the state and the defendant. Second, courts

The efficient use of Criminal Justice Act funds to pay and reimburse defense counsel is a very practical reason why our system of justice should require the government's counsel to provide the Brady ... information to defense counsel rather than have defense counsel use their time and the sparse CJA funds to try to gather information favorable to the defense which is already in the government counsel's possession.

United States v Burnside, 824 F Supp 1215, 1261 (N D Ill 1993). See also People v Ranghelle, 69 NY2d 56, 511 NYS2d 580, 585 (1986) ("Where... the existence of [the exculpatory material] is readily ascertainable by the prosecutor, there is no reason to dilute the [prosecutor's] obligation by holding that defense counsel should have himself subpoenaed the document."). 
may wish to characterize the Brady rule as a duty of prosecutors because of the unique role they play in the justice system. The government prosecutor is not an ordinary adversarial attorney. $\mathrm{He}$ "is the representative not of an ordinary party to a controversy, but of a sovereignty . . . whose interest . . . in a criminal prosecution is not that it shall win a case, but that justice shall be done. ${ }^{75}$

Nonetheless, to conceive of Brady as simply the prosecutor's duty is mistaken. To be sure, Brady imposes special duties on the prosecutor, but it also reaches all state agents. Investigative officers who represent the state also should share an interest in seeing that justice be done, as should all state actors. Anyone who plays a part in bringing the power of the state to bear on the individual in the form of punishment must share the responsibility to uncover the truth that comes with that power. Brady violations need not emanate from the prosecutor or even from the prosecutor's office alone. Any state officer can violate $B r a d y,{ }^{76}$ and it would be easier to analyze Brady violations if the courts recognized this fact expressly.

\section{The Supreme Court and the duties of nonprosecutors.}

The Supreme Court has never explicitly said that nonprosecutors share Brady obligations with prosecutors. Still, the Court's rationale in key cases implicitly recognizes the duties of nonprosecutors. The Court rooted Brady's obligation to search for the truth in the Due Process Clause. The prosecutor owes the defendant a process in which the prosecutor makes a reasonable effort to uncover the truth. Part II.B described how a court determines whether the prosecutor made such a reasonable effort-whether the prosecutor uncovered evidence and disclosed evidence favorable to the accused that the prosecutor should have known about. But cases following Brady have made it clear that a failure to make a reasonable effort to uncover the truth is not essential to a Brady violation. ${ }^{77}$

75 Berger v United States, 295 US 78, 88 (1935).

${ }^{76}$ See Barbee $v$ Warden, Maryland Penitentiary, 331 F2d 842, 846 (4th Cir 1964) ("[T]t makes no difference if the withholding [of material and exculpatory evidence] is by officials other than the prosecutor.").

77 Improper conduct by some state actor, however, is essential to a Brady violation. See text accompanying note 107.

Giglio was the first case suggesting that Brady duties extended beyond the prosecutor. 405 US at 154. In that case, the trial prosecutor was held responsible for evidence held by another prosecutor in his office. Knowledge of the evidence was imputed to the 
In Kyles, the Court held that "the prosecutor remains responsible for [Brady material] regardless of any failure by the police to bring favorable evidence to the prosecutor's attention."78 $T$ The Court made clear that:

the individual prosecutor has a duty to learn of any favorable evidence known to the others acting on the government's behalf in the case, including the police. But whether the prosecutor succeeds or fails in meeting this obligation ... the prosecution's responsibility for failing to disclose known, favorable evidence rising to a material level of importance is inescapable. ${ }^{79}$

The Kyles Court said that Brady imposes a duty on the prosecutor to learn of favorable evidence held by the police. That is, the prosecutor is strictly liable for failing to discover material evidence favorable to the accused and held by the police. Here, the prosecutor can violate the Due Process Clause without ever having done anything wrong. His search for the truth may have been diligent; it may have been all that anyone could ask of a conscientious prosecutor. Nonetheless, if the prosecutor's best effort fails to produce the proper result-actual discovery of the evidence-the Court says that the prosecutor violated the Due Process Clause. ${ }^{80}$

The Due Process Clause was indeed violated in Kyles, but it seems more accurate to say that the police, rather than the prosecutor, violated Brady when they concealed evidence favorable to the accused. To say that the prosecutor in Kyles has Brady duties even when not at fault is to recognize that due process requires the police to turn such evidence over to the prosecutor. The Kyles Court chose, following convention, to characterize the duty as the prosecutor's. But when police do not turn over the requested evidence, it makes little sense to locate the violation of the Due Process Clause in the prosecutor's failure to disclose it.

trial prosecutor even though the trial prosecutor had asked the other prosecutor whether he had the evidence and was told falsely that there was no evidence. Id at 152. Almost surely, the trial prosecutor was justified in believing the other prosecutor. Still, the Supreme Court's discussion of the issue is brief and ambiguous. Kyles makes the point more clearly. $115 \mathrm{~S} \mathrm{Ct}$ at 1555.

${ }^{28} 115 \mathrm{~S} \mathrm{Ct}$ at 1560.

79 Id at 1567-68 (citations omitted).

80 Police officers can conceal evidence from even the most diligent prosecutor, since a prosecutor must rely on the judgment of the police in responding to his requests. It would waste the prosecutor's time and demean the integrity of the police to expect the prosecutor to sift through the files of police investigators. 
The Kyles Court in fact explained why Brady obligations must extend to the police, even when the prosecutor acted reasonably. "[A]ny argument for excusing a prosecutor from disclosing what he does not happen to know about boils down to a plea to substitute the police for the prosecutor, and even for the courts themselves, as the final arbiters of the government's obligation to ensure fair trials." ${ }^{n 1}$ The Court was apparently concerned that overzealous or corrupt police officers might intentionally conceal evidence from the prosecutor. ${ }^{82}$ The defendant should not suffer when the police have kept the prosecutor in the dark. The Brady remedy of a new trial deters unfair conduct by state actors, police and prosecutors alike. ${ }^{83}$

\section{The lower courts and the duties of nonprosecutors.}

Some courts have come close to explicitly recognizing that Brady imposes duties on state agents beyond the prosecutor's office. When the defense files a pretrial search Brady request, the prosecutor need not personally examine a file (for example, an agent-witness's personnel file) that may contain evidence favorable to the defense. Rather, it is sufficient if the state officer in possession of the file examines it for favorable evidence. ${ }^{84}$ If the

81 Kyles, $115 \mathrm{~S}$ Ct at 1568.

22 See also Jones $v$ City of Chicago, 856 F2d 985, 995 (7th Cir 1988) (finding a Brady violation in police "attempts to circumvent the rule . . . by retaining records in clandestine files deliberately concealed from prosecutors").

3evertheless, independent discovery of evidence that the government has not disclosed is rare, and Brady probably has little deterrent effect on thoroughly corrupt officials. Brady may, however, encourage well intentioned prosecutors, police, and other officials to deal responsibly with the conflicting impulses of law enforcement, reinforcing their sense of procedural fairness. In fact, Brady may bolster the sense of obligation to promote fairness in any state actor who knows that she is in a position to affect the outcome of a trial.

Although Brady imposes extensive obligations on states to uncover the truth, defense attorneys still must be aggressive with requests for evidence. Even well meaning state officials are not as attuned to the potential that evidence will benefit the accused as are defense attorneys. Unless the state official recognizes the favorable character of the evidence, he will not disclose it. Further, the materiality standard allows some favorable evidence to go undisclosed, so a defense attorney relying simply on the government's Brady obligations will not see all of the favorable evidence available. Finally, the remedy for a Brady violation arrives post-conviction, after much damage to one's client has already been done and cannot be undone.

84 See, for example, United States $v$ Smith, 552 F2d 257, 261-62 (8th Cir 1977) (holding Brady obligations satisfied when Drug Enforcement Agency screened its own files for favorable evidence); United States $v$ Jennings, $960 \mathrm{F2d} \mathrm{1488,} 1492$ (9th Cir 1992) (endorsing Justice Department policy allowing individual law enforcement agencies, rather than local prosecutors, to screen their files for Brady material); Commonwealth $v$ Donahue, 396 Mass 590, 487 NE2d 1351, 1357-58 (1986) ("[T]he prosecutor's only respon- 
examining officer determines that the file contains no material and favorable evidence, he so informs the prosecutor, and neither the prosecutor nor the defense actually views the file. ${ }^{85}$ While this procedure allows other state agents to discharge and, at least in some sense, assume part of the prosecutor's search Brady obligations, ${ }^{86}$ the courts have chosen not to view it that way. Instead, they correctly (but unsatisfyingly) hold that "the prosecutor may be charged with the consequence of not having produced [the evidence] if this has the effect of denying the accused a fair trial." ${ }^{\prime 87}$ Admittedly, these cases show only that Brady duties can involve nonprosecutors, but other cases show more.

The facts of Commonwealth $v$ Donahue are illustrative. ${ }^{88}$ The defendant was convicted of bank robbery in Massachusetts state court. Both federal and state authorities investigated the crime, although they apparently did not coordinate their investigations. The defendant had hoped to present an alibi defense. Unfortunately for him, his alibi witness, who was in the Federal Witness Protection Program, refused to speak with the defense, although he did speak on separate occasions with both federal and state agents. The state prosecutor turned over the information he obtained through his interview, but the FBI agent who had interviewed the witness refused to disclose his notes, claiming that they contained nothing helpful to the defense. The information that the state prosecutor disclosed proved insufficient to support the alibi, and the defendant chose not to call the witness. However, the information in the FBI agent's notes strongly supported the alibi. ${ }^{89}$

The Massachusetts Supreme Judicial Court faulted the state prosecutor for failing to seek the cooperation of the FBI, and it held that the state prosecutor's failure denied the defendant a

sibility was to pass the request [for Brady material] along to the appropriate Federal officials and to transmit the Federal response to counsel.").

85 Smith, 552 F2d at 261-62 (finding sufficient DEA assurances that their files did not contain any exculpatory evidence).

${ }^{86}$ While the prosecutor's obligations shift to the examining agent, the prosecutor's special knowledge does not. The prosecutor has both intimate familiarity with the facts of the case and special legal knowledge. The prosecutor may thus assess more accurately the significance of the evidence at issue. Since materiality must be judged in terms of all of the evidence available in the case, Kyles, $115 \mathrm{~S} \mathrm{Ct}$ at 1567, the state agent should resolve doubtful questions in favor of disclosure to the prosecutor who then can exercise his own expert judgment regarding the significance of the evidence. See Jennings, 960 F2d at 1492.

${ }^{87}$ Smith, 552 F2d at 262.

396 Mass 590, 487 NE2d 1351, 1353-58 (1986).

20 Id at 1353-54. 
fair trial. ${ }^{90}$ But that is not the whole story. The court recognized the possibility that the FBI would have refused to cooperate with state prosecutors even had the state sought FBI assistance. The court refused to "speculate on the further responsibilities, if any, the prosecutor may have had if the Federal authorities had declined to cooperate." ${ }^{\prime 91}$ That is, even if the FBI agent refused to disclose his notes to the prosecutor, the court presumably would have considered only the state prosecutor's responsibilities. Instead, the court should have considered the FBI agent's responsibility to ensure a fair trial.

A few cases have explicitly held that government agents other than prosecutors have Brady obligations. For example, in United States $v$ Wood, the defendant was convicted of "obstructing the FDA's function of ensuring that prescription drugs are safe and effective and dispensed pursuant to a prescription from a practitioner licensed by law to administer such drugs. ${ }^{.92}$ A key prosecution witness had testified that the drugs dispensed by the defendant were dangerous to humans. However, the FDA had in its files a report that showed that the drugs in question were not dangerous to humans. ${ }^{93}$ The court recognized that the prosecutor did not know about the precise contents of the file, but the FDA did. As a result, the court held that "the FDA failed to discharge its [Brady] obligation of disclosure."94

The Wood court's reasoning suggests that the FDA agents had an obligation of disclosure only because they had "consulted with the prosecutor in the steps leading to the prosecution."95 The court did not hold that state agents generally have an obligation to disclose exculpatory evidence whenever they know of its existence. Rather, it held that the FDA's cooperation with the prosecution imposed Brady duties on the agency. In addition, the court emphasized that the FDA is "the agency charged with administration of the statute. ${ }^{\$ 96}$ The result should not be different if the FDA had not cooperated in the prosecution but was still aware of the trial. Any rule restricting the obligations of disclosure only to those cooperating in the prosecution would endorse

so Id at 1358 ("[T] the defendant access to material exculpatory evidence.").

91 Id.

s2 57 F3d 733, 735 (9th Cir 1995).

93 Id at 737.

94 Id at 735 .

95 Id at 737.

96 Id. 
an indifference to the truth "unworthy of representatives of the United States Government. ${ }^{n 97}$

Cases in both the Supreme Court and in lower courts show that Brady obligations apply to nonprosecutors. ${ }^{98}$ The next Section addresses the proper analysis of those obligations.

\section{B. The Scope of Nonprosecutors' Brady Obligations}

Recognizing that Brady imposes duties on all state actors improves the analysis of search Brady claims. Such claims can succeed on two different bases. The prosecutor may have failed to fulfill his general search Brady obligations. Alternatively, the state actor in possession of the evidence may have failed to fulfill his Brady obligations. Part II.B above discussed the factors courts should employ to determine the scope of the prosecutor's search Brady obligations.99 This Part analyzes how courts should determine the scope of other state agents' Brady obligations.

While Brady imposes duties on all state agents, the differences between the prosecutor and all other state agents affect the extent of their duties. First, the prosecutor is an officer of the

${ }_{97}$ Auten, 632 F2d at 481. For other cases imposing Brady obligations beyond prosecutors, see Barbee, $331 \mathrm{~F} 2 \mathrm{~d}$ at 846 ("The duty to disclose is that of the state, which ordinarily acts through the prosecuting attorney; but if he too is the victim of police suppression of the material information, the state's failure is not on that account excused."); United States $v$ Bryant, $439 \mathrm{~F} 2 \mathrm{~d} 642,650$ (DC Cir 1971) ("The duty of disclosure affects not only the prosecutor, but the Government as a whole, including its investigative agencies.").

98 The holding of Arizona $v$ Youngblood, 488 US 51 (1988), is not to the contrary. In that case, the Supreme Court held that a defendant needs to show bad faith on the part of the police in order to state a due process claim for failing to preserve potentially useful evidence. Id at 58. There are good reasons to distinguish Youngblood and refuse to apply its higher standard of police culpability in the Brady context. First, a classic Brady violation occurs "irrespective of the good faith or bad faith of the prosecution." Brady, 373 US at 87. Once we recognize that other state actors also have Brady obligations, there is no reason to apply a different standard to them. Second, Youngblood dealt with only the preservation of potentially exculpatory evidence. When such evidence is not preserved, there is no way to know whether the failure to preserve it resulted in the loss of evidence that would have been favorable to the defense. Youngblood requires a showing of bad faith to bolster the inference that the police had something to gain by destroying the evidence-an inference that supports the conclusion that the evidence lost was favorable to the defense. When the evidence still exists, as in the Brady context, we can examine it to determine its exculpatory character, and we need not use the level of police culpability as a surrogate. Youngblood, 488 US at 57-58. Third, the remedy in cases involving destruction of potentially exculpatory evidence has to be acquittal. A new trial would be fruitless because the disputed evidence has been destroyed. This dramatic and irreversible result justifies imposing the tough burden on the defendant. In Brady cases, the court orders the less dramatic new trial remedy.

99 See text accompanying notes 56-74. 
court. He bears a greater responsibility for the integrity of the proceeding than do other state actors. The prosecutor is especially responsible, as the government's representative in court, for fairness. He has a special responsibility to ensure that the evidence presented is truthful and that the government presents a complete story to the court. Second, the prosecutor is the captain of the state's team. "A prosecution that withholds evidence ... which, if made available would tend to exculpate [the accused] ... casts the prosecutor in the role of an architect of a proceeding that does not comport with standards of justice." The prosecutor, as head of the team that presents the government's story in court, is responsible for all parts of the story in a way that other state actors are not.

Although Brady imposes an obligation on the prosecutor to search for evidence not in his possession, this Comment suggests that its rationale does not impose that obligation on other state actors. Rather, Brady requires other state actors to disclose evidence in their possession that they know ${ }^{101}$ can help exculpate the accused. In other words, prosecutors have search Brady and classic Brady obligations, while other state actors have only classic Brady obligations. ${ }^{102}$ To see why, we must describe how a nonprosecutor can respond when she learns of evidence potentially favorable to the defense not in her possession.

Assume that a nonprosecutor is alerted to the possibility that a file held by another state agent may contain exculpatory evidence. Assume further that the nonprosecutor has not seen the file and cannot assess its potential value to the defense, but knows that the possibility is more than "utter speculation."103 Since the nonprosecutor is not the captain of the government's team, she need not examine the file herself. Indeed, she may not have the power to compel the other state agent to surrender it to

100 Brady, 373 US at 87-88.

101 The relevant knowledge here is knowledge learned in connection with one's role as a state agent. For example, if a friend of a Labor Department statistician tells her that he committed a crime of which another man is accused, the Due Process Clause does not require her to disclose the confession to the prosecutor. In such a case, the individual as state agent does not have the knowledge, only the individual as private citizen.

${ }^{102}$ The prosecutor may, however, ask a state agent to satisfy the prosecutor's search Brady obligations by reviewing a file in the state agent's possession for exculpatory evidence. See text accompanying notes $85-87$. This procedure triggers the state agent's classic Brady obligations but does not impose search Brady obligations on her.

103 See United States $v$ Brooks, 966 F2d 1500, 1504 (DC Cir 1992) (noting that suspicion of finding exculpatory evidence which rises above utter speculation can trigger the prosecutor's search Brady duties). 
her. Still, the nonprosecutor does have classic Brady obligations. Classic Brady obligations include the duty to disclose the possibility of evidence favorable to the defense to individuals capable of making the inquiry. ${ }^{104}$ This duty requires the nonprosecutor to inform the prosecutor (or the defendant) of the basis of her suspicion if she cannot, or will not, undertake the effort to uncover the truth herself.

Imposing search Brady obligations on all state actors, then, is unnecessary. For whenever nonprosecutors know enough to trigger the search Brady obligations of a prosecutor, they must pass that knowledge on to the prosecutor or the defense. Once the appropriate people have such knowledge, Brady obligations can work in their ordinary fashion to ensure that the truth emerges. ${ }^{105}$ Imposing search Brady obligations on nonprosecutors would add little if any protection to defendants. Further, it would not aid the search for truth because it would often pointlessly impose a duty to obtain a file on a person incapable of obtaining it. ${ }^{106}$

Search Brady analysis, thus, recognizes that the Due Process Clause is violated whenever the prosecutor does not disclose evidence favorable to the defense that the prosecutor should have known about. Sometimes, he may not know of the evidence because of his own failure; other times other state agents may fail

${ }^{104}$ United States $v$ Shaffer, 789 F2d 682, 690 (9th Cir 1986), citing United States $v$ Griggs, 713 F2d 672, 674 (11th Cir 1983).

${ }_{105}$ To be sure, bureaucracies are not terribly responsive institutions. Recognizing the Brady obligations of all state actors will not suddenly set in motion the vast machinery of the state to uncover the truth in criminal trials. However, recognizing the constitutional responsibility of bureaucrats can affect how they perceive their jobs, which can alter their behavior.

Further, the analysis of Brady presented here places a fairly substantial burden on the state. The costs of educating all state employees about their obligations under Brady and of putting in place a mechanism for reporting evidence to the prosecutor may be large. In fact, if the costs are very substantial, a state may choose not to undertake them, preferring instead to incur the costs of the occasional post-conviction reversal under Brady. These cost calculations explain why the expansion of Brady here proposed may not alter the behavior of state actors very much. But it does not follow that courts should ignore the state's constitutional violation when a particular defendant is fortunate enough to discover it.

${ }^{106}$ Recognizing the classic Brady obligations of state actors other than prosecutors does create a somewhat awkward terminology. A search Brady claim may succeed due to the failure of a nomprosecutor to satisfy his classic Brady obligations. The peculiarity stems from how search Brady claims are defined, namely, as all Brady claims based on evidence not known to the prosecutor. See text accompanying note 18. But although the terminology may be awkward, the analysis is not. 
him. Either way, the defendant is denied due process by a state agent.

\section{IMPLICATIONS OF NONPROSECUTORS' BRADY OBLIGATIONS}

Recognizing that all state agents have Brady obligations offers a superior explanation for the cases. For example, it helps locate the constitutional error. If only prosecutors have Brady obligations, then the Kyles court found a violation of the Due Process Clause in the absence of any wrongful behavior. The prosecutors in those cases acted reasonably in their efforts to present the truth to the court. To find a Due Process Clause violation in their conduct separates due process analysis from its principle.

Due process is not denied unless some state actor acted improperly, at least negligently, in his effort to uncover the truth. It is logically possible to find a violation of the Due Process Clause even in the absence of any negligent conduct. ${ }^{107}$ As we have seen, the Supreme Court does not require negligence by the prosecutor. ${ }^{108}$ But the Court holds prosecutors strictly liable for practical reasons. It wants to be sure that the defendant does not suffer because investigators kept the prosecutor in the dark. To extend this strict liability to all state actors places an impractical burden on the state. It is unrealistic to expect all state actors to become familiar with every criminal case and determine whether there is buried somewhere in their files evidence favorable to the accused. There may be cases in which the exculpatory evidence was in the government's possession, but it was unreasonable for

107 One case suggests that negligent conduct by the state is irrelevant and cites Supreme Court language to support that proposition. Walker v A.L. Lockhart, 763 F2d 942, 959 (8th Cir 1985), citing United States v Agurs, 427 US 97, 110 (1976) (arguing that "the State's constitutional obligation is not measured by [a police officer's] willfulness or negligence"). But a careful look at the Supreme Court's language shows that the Court has recognized only that negligence by the prosecutor in search Brady cases is not essential. See Agurs, 427 US at 110 ("If the suppression of evidence results in constitutional error, it is because of the character of the evidence, not the character of the prosecutor.") (emphasis added); Smith v Phillips, 455 US 209, 219 (1982) ("[T]he touchstone of due process analysis in cases of alleged prosecutorial misconduct is the faimess of the trial, not the culpability of the prosecutor.") (emphasis added).

Since the Court has not explicitly recognized the Brady obligations of all state actors, it has not spoken directly about whether negligence by some state actor is necessary to support a Brady claim. However, Walker's language is broader than necessary to reach its result. The court recognized that "the significance of [the evidence] should not have been lost on [the police officer]." Walker, 763 F2d at 958-59. The officer had a classic Brady obligation to disclose the evidence to the prosecutor, if not the defendant.

${ }^{108}$ See text accompanying notes 78-83. 
any state actor to realize its significance to a criminal trial. ${ }^{109}$ Such claims are properly brought under Rule 33 of the Federal Rules of Criminal Procedure asserting newly discovered evidence, ${ }^{110}$ not under Brady. In such cases, the defendant is not denied something promised him by the Constitution. The Due Process Clause promises no more (but also no less) than the reasonable effort of state agents serving the truth.

In addition, recognizing the Brady obligations of all state agents provides a clear legal reason why it makes little sense to limit Brady claims to cases in which the agent possessing the evidence is under the same sovereignty as the prosecutor. ${ }^{11}$ Possession by any government agent should do. The Supreme Court grounded Brady in principles of due process. The Fifth Amendment's Due Process Clause controls the federal government and the Fourteenth Amendment's Due Process Clause controls state governments. The approach presented here recognizes that both Clauses operate at the same time, but especially in cases involving cooperation between state and federal authorities. Perhaps a federal prosecutor does not violate Brady when he fails to discover exculpatory evidence hidden from him by state agents. But the state agent does violate Brady.

Beyond promoting intellectual coherence, recharacterizing Brady obligations can change the results of some cases. A prosecutor's search Brady obligations will often overlap with another state agent's classic Brady obligations, but each captures cases not caught by the other.

${ }^{109}$ See Joseph, 996 F2d at 40-41, discussed at text accompanying notes 57-58; Bell v Coughlin, 820 F Supp 780, 787 (S D NY 1993), aff'd, 17 F3d 390 (2d Cir 1993), cert denied, 114 S Ct 2685 (1994) (A state investigator physically possessed a ballistics report that contained exculpatory information, but he did not have knowledge of the report's contents because it was buried in a 108-page document prepared by the FBI.).

${ }^{110}$ The basic requirements for a successful claim under Rule 33 are: “(1) The evidence is newly discovered and was unknown to the defendant at the time of trial; (2) Failure to detect the evidence was not due to lack of due diligence by defendant; (3) The evidence is material, not merely cumulative or impeaching; and (4) The evidence will probably produce an acquittal." United States $v$ Peña, 949 F2d 751, 758 (5th Cir 1991). There are three important differences between Brady and Rule 33. First, Brady requires that the evidence create a "reasonable probability that ... the result of the proceeding would have been different." United States $v$ Bagley, 473 US 667, 682 (1985). Rule 33 asks more: the evidence must probably produce an acquittal. Second, while impeachment evidence can be Brady material, see note 11, mere impeachment evidence will not earn a new trial under Rule 33. Finally, motions for a new trial based on newly discovered evidence must be made within two years after final judgment. FRCrP 33. There is no time limit on Brady claims. 
We have already seen cases in which the prosecutor's search Brady obligations, and not anyone else's classic Brady obligations, encourage full disclosure of the state's evidence bearing on the truth. For example, requiring the prosecutor to acquire the criminal record of a government witness does not implicate anyone's classic Brady obligations, since the state agents in possession of the records almost surely are unaware that the subject of the records will testify in a criminal trial. ${ }^{112}$ Classic Brady obligations alone would not cover this basic case.

Likewise, imposing classic Brady obligations on all state actors will reach cases not covered by the prosecutor's search Brady obligations. Recognizing the classic Brady obligations of all state actors may change the result in high-profile cases. As the facts of a trial and its details become more widely known, it becomes more likely that some state agent will realize that information in his files may be favorable to the defense.

More importantly, the facts of People $v$ White illustrate how extending classic Brady duties to all state agents may benefit criminal defendants generally, not just the few whose trials attract significant media attention. ${ }^{113}$ The defendant was arrested on a rape charge while on parole for another offense. His parole officer conducted an investigation into the incident, which included an interview with the arresting officer. Records of those interviews could have contained information favorable to the accused. Since the parole officer had conducted the investigation for purposes independent of the prosecution (a parole revocation proceeding), the court held that he had no connection to the prosecutor. ${ }^{114}$ Since the prosecutor was actually unaware of the existence of the report and had no connection with the state agent who prepared it, no Brady violation would arise under the standard view. ${ }^{115}$

Recognizing that the parole officer has classic Brady obligations could change the result. If the parole officer knew that the records in his possession were favorable to the defense, then he violated the Due Process Clause by not turning them over to the defense or at least notifying the prosecutor. For example, the parole officer's report may have contained contradictory factual

112 See text accompanying note 64 .

213210 AD2d 447, 620 NYS2d 437, 437-38 (NY App Div 1994).

114 Id.

115 Perhaps, however, the defendant could still compel examination of the records by making a specific request for them. See text accompanying notes 66-70. 
statements by witnesses. The parole officer was surely in a position to recognize evidence favorable to the defense; he knew why the defendant had been arrested and what he was accused of doing. If the parole officer's investigation uncovered favorable evidence, the state should not be able to keep it secret merely because it was not prepared for use by the prosecutor.

Of course, the parole officer's report may also have contained favorable evidence that the parole officer reasonably could not recognize. If a witness's statement at trial conflicts with his statement to the parole officer, and the parole officer did not follow the trial, the parole officer could not know of the conflict. In the absence of such knowledge, the parole officer's classic Brady obligation to disclose the report is not triggered. In fact, under these circumstances, assuming that the parole officer has never shown his report to the prosecutor, it is unreasonable to expect any state agent to know that the exculpatory evidence exists. ${ }^{116}$ This evidence, if it emerges, is properly treated not under Brady, but as newly discovered evidence under Rule 33 of the Federal Rules of Criminal Procedure.

However, the analysis changes if the witness whose testimony differs from his statements to the parole officer is himself a state agent, perhaps a police officer. If a police officer knows that the parole officer has evidence that could be used to impeach his credibility, the police officer should disclose this fact to the prosecutor, who should, in turn, disclose it to the defendant. Stated broadly, all testifying state agents have a classic Brady duty to disclose evidence that materially undermines their credibility.

The police officer's obligation to disclose evidence undermining his credibility has powerful potential. It suggests a new line of attack for defendants wishing to challenge a conviction based on testimony from an officer who has engaged in misconduct, such as perjury or extortion, prior to trial. Some courts have not been receptive to claims that the government suppressed evidence when that claim is based on the discovery that a police officer, who testified at trial, had in the past engaged in illegal activity which could be used for impeachment. For example, a New York appellate court held that when police officers engage in misconduct, they act "not in furtherance of law enforcement but rather in pursuit of an unlawful scheme of their own ...."117

116 To be sure, the state's witness himself holds the favorable information; he alone knows of both statements. But, assuming the witness is not himself a state agent, his knowledge cannot be attributed to the state.

${ }^{117}$ People v Vasquez, 214 AD2d 93, 631 NYS2d 322, 326 (NY App Div 1995), citing 
That is, police officers who engage in misconduct are not state actors when they so act. Therefore, when they conceal such behavior, there is no Brady violation because (even under this Comment's broadened view) Brady duties apply only to state actors.

But such analysis misses the point of Brady. Perhaps the officer was not a state actor when he engaged in the underlying corrupt conduct, but he was a state actor when he testified against the defendant and concealed his misconduct from the defense. There can be no doubt that the officer knew that the evidence, which bears on his credibility, is favorable to the defense. If the evidence satisfies the standard of materiality, then his failure to disclose it violates $B r a d y .{ }^{118}$ It may be unreasonable to expect that officers will disclose their misconduct; they probably will not. However, this does not cure the Brady violation if the defendant is fortunate enough to learn of the corruption after his trial. ${ }^{119}$

Commonwealth $v$ Waters, 410 Mass 224, 571 NE2d 399, 402 (1991) (arguing that "the corrupt officer is not acting as an 'arm of the prosecution' when he or she is concealing his or her own criminal activity, unrelated to the case against a particular defendant").

${ }_{118}$ The Supreme Court of New Jersey has ordered a hearing to determine the sufficiency of the evidence supporting the conviction in a case in which the defendants, convicted of drunk driving, discovered after trial that the police officer had falsified breathalyzer results in prior cases. State $v$ Gookins, 135 NJ 42, 637 A2d 1255, 1256-58 (1994). In addition, the Supreme Court of Appeals of West Virginia responded similarly to the discovery that a forensic serologist systematically falsified his reports, ordering new trials in all cases in which his testimony had a material effect on the verdict. In re an Investigation of the W Va State Police Crime Lab, Serology Div, 190 W Va 321, 438 SE2d 501,506 (1993). Neither of these results rested on the rationale that the corrupt official violated Brady. Rather, both cases relied on the fact that the misconduct was so pervasive that the court could treat the corrupt officer's testimony as false in each prior case. In re W Va State Police, 438 SE2d at 504, 506; Gookins, 637 A2d at 1260. This rationale is probably correct, but it should only apply in extreme circumstances. A state agent can engage in conduct that undermines his credibility-evidence of which is favorable to the defense-without that conduct being so pervasive as to justify an inference that all of the agent's prior testimony was false.

129 Admittedly, this analysis has potentially broad consequences. It suggests that if a police officer perjured himself five years ago, and we have learned of it after he has since testified in $\mathbf{5 0 0}$ cases, then all $\mathbf{5 0 0}$ convicts should get a materiality hearing to determine whether Brady requires a new trial. Perhaps the fear of a flood of Brady claims motivated the mistaken analysis in Vasquez. Indeed, courts may need to develop procedural devices to deal with these claims quickly and to weed out the frivolous ones. For example, courts could borrow from Franks $v$ Delaware, 438 US 154 (1978), and require, in cases where the Brady claim is based on police misconduct unrelated to the case, that the defendant make a "substantial preliminary showing" of materiality before the court will entertain the claim. (Franks establishes a procedure for defendants to challenge the veracity of a police officer's facially sufficient warrant affidavit.) It is beyond the scope of this Comment to hash out the procedural details associated with the expansion of Brady to all state actors. Instead, this.Comment demonstrates that prior police misconduct raises serious Brady 


\section{CONCLUSION}

The Brady rule aims at discovering the truth and achieving faimess in the criminal process. Courts must take the utmost care when there is reason to doubt the accuracy of a conviction. When state actors have in their possession evidence that raises such doubts, then the courts must make them produce it. Unfortunately, the various circumstances under which the state should be expected to uncover exculpatory evidence buried in its vast files do not lend themselves to a precise rule. Still, courts can do better than they have. They can recognize that all state agents share Brady duties. Doing so will put all state agents on notice that they must play their part in ensuring that the truth emerges in criminal proceedings. Further, courts can recognize all of the relevant factors of search Brady claims and discuss how they interact in each case. Greater clarity in the analysis will better guide the well meaning prosecutor and investigator, ensuring that they are not the tools of arbitrary power but contributors to a system that dispenses justice. 
